\title{
Neonatal Tetanus in the Department of Child Health Dr. Pirngadi Hospital, Medan in 1983-1984
}

\author{
by \\ MANIHAR D. MARBUN, JOHNNY ARSYAD, MUNAR LUBIS, ENDANGD. \\ HAMID and CHAIRUDDIN P. LUBIS
}

(From the Department of Child Health, School of Medicine, University of North Sumatera, Medan, Indonesia)

\begin{abstract}
From January 1983 to December 1984 there had been prospective investigations of neomatal teamus commacted by newhorn infants treated at the Department of

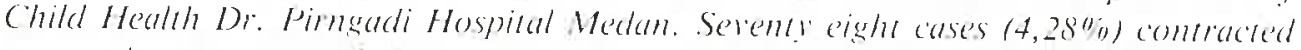

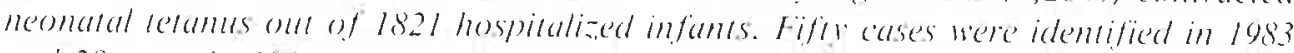

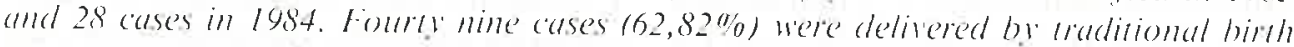

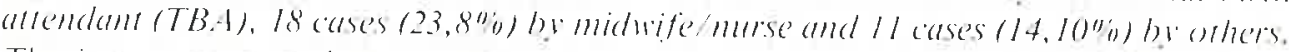

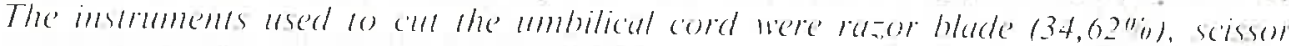

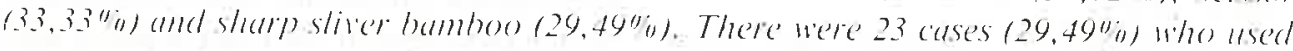
traditional medicine made from herb for ambilical cord treatment. None of the mothers was vacinated with retamus loxoid. Most of the parents had only elememary school education, 42,32\% fathers and $71,79 \%$ mothers.

Based on this stud! it is suggested to increase tetamus toxoid immunizationn an

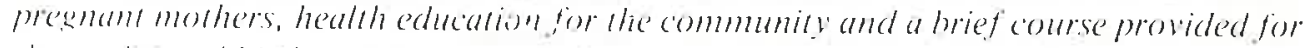

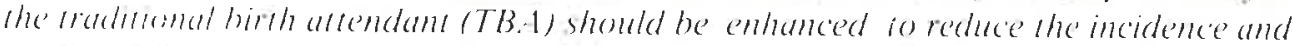

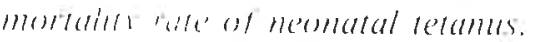




\section{Introduction}

Neonatal tetanus just like tetanus, is a caused by several factors. The predominant common health problem in the world especially in developing countries (Dibyosubroto, 1980; Hasan, 1981). Khoo (1981) estimated 80 - 320 cases out of 1.0r.) live births. In developed countries such as the United States and the United Kingdom, this disease had rarely been prevalent (Hutchison, 1984).

The neonatal tetanus mortality rate in some hospitals in Indonesia reached $35 \%$ - 96\% (Sunarto and Budiman, 1972; Tjaij and Sembiring, 1972; Marwoto and Surjono, 1976; Napitupulu, 1976; Husada et al., 1976; Ruspanji, 1981; Sudaryat et al., 1981; Ismudijanto et al., 1981; Saragih et al., 1981; Hamid et al., 1985), indicates a high percentage of deaths. In 1983 the number of cases and deaths caused by neonatal tetanus was estimated to be 89,250 and 80,325 cases respectively (quoted from Umpan Balik EPID 1984). The high frequency of neonatal tetanus in Indonesia is ones are the insufficient immunization upon pregnant mothers or fertile women while $80-90 \%$ of deliveries were attended by traditional birth attendants (TBA). This indicated that the role of TBA is still dominant (Marwoto and Surjono, 1976; Prawirohujo, 1980). Other factors that caused the high occurrence of neonata tanus are environmental sanitation, ignorancy of health and sterility, the existence of traditional beliefs or habits, the low level of socio economic condition. (Dibyosubroto et al.,|1978; Prawirohujo, 1980; Ruspanji, 1981; Sudaryat et al., 1981). The purpose of this study is to investigate neonatal tetanus with respect to following aspects: the person attending the delivery, the instruments used for cutting the umbilical cord, parents education, mortality rate and immunization status of the mothers whose babies suffered from neonatal tetanus.

\section{Materials and Methods}

This study was conducted prospectively on neonates admitted with neonatal tetanus in the Department of Child Health, Dr. Pirngadi Hospital during the period of 23 months between January 1983 and December 1984.

The informations including age, birth attendant, kinds of instruments used for cutting umbilical cord, material used for the treatment of the umbilical stump, parent's educational back ground and mother's immunization status were re-

corded in a special form.

All cases were regularly reported to the Provincial Health Department of North Sumatera and to the Municipal Health Service or District Health Service. Detailed information concerning labor procedures, cutting of umbilical cord and material used for the treatment of umbilical stump was taken from the birth attendant. Report on these cases were then sent to the Department of Child Health, Dr. Pirngadi Hospital, Medan.

\section{Result}

During the above mentioned period, 78 the Department of Child Health, Dr. Pircases of neonatal tetanus were treated in ngadi Hospital, Medan.
Table 1 : Number of cases

\begin{tabular}{cccccccc}
\hline \multirow{2}{*}{ Year } & \multicolumn{3}{c}{ Total cases } & \multicolumn{5}{c}{ Neonatal tetanus } & $\%$ \\
\cline { 2 - 6 } & M & F & Total & M & F & Total & \\
\hline 1983 & 516 & 397 & 913 & 24 & 26 & 50 & 5,48 \\
1984 & 538 & 370 & 908 & 15 & 13 & 28 & 3,08 \\
\hline Total & 1054 & 767 & 1821 & 39 & 39 & 78 & 4,28 \\
\hline
\end{tabular}

$\mathbf{M}=$ male $\quad \mathbf{F}=$ female

Fifty cases out of 913 infants and 28 cases out of 908 admitted in 1983 and 1984

espectively. They were 39 males and 39 (table 1).

Table 2 : Birth attendant and neonatal tetanus

\begin{tabular}{lcccccc}
\hline Birth Attendant & \multicolumn{2}{c}{1983} & \multicolumn{2}{c}{1984} & Total & $\%$ \\
\hline Tumber & $\%$ & Number & $\%$ & & \\
Midwife/nurse & 30 & 38,46 & 19 & 24,36 & 49 & 62,82 \\
D o c t o r & 12 & 15,38 & 6 & 7,70 & 18 & 23,08 \\
Others & - & - & - & - & - & - \\
\hline T o t a l & 8 & 10,26 & 3 & 3,84 & 11 & 14,10 \\
\hline
\end{tabular}

Table 2 shows that 49 cases $(62,82 \%) \quad(11,10 \%)$ attended by mothers, fathers, were delivered by TBA, 18 cases $(23,08 \%)$ grandmothers and neighbours (others). by midwife/nurse. There were 11 cases Only 3 out of $49 \mathrm{TBa}$ were trained $(6,01 \%)$. 
Table 3 : Instrument used for cutting the umbilical cord

\begin{tabular}{lcrrrrrrrr}
\hline \multirow{2}{*}{ Instrument } & \multicolumn{2}{c}{ T B A } & \multicolumn{2}{c}{ Mid/Nur } & \multicolumn{2}{c}{ Rel } & Total & $\%$ \\
\cline { 2 - 7 } & Number & $\%$ & Number & $\%$ & Number & $\%$ & & \\
\hline Scissor & 6 & 7,69 & 18 & 23,08 & 2 & 2,56 & 26 & 33,33 \\
Bamboo & 20 & 25,64 & - & - & 3 & 3,85 & 23 & 29,49 \\
Razor blade & 22 & 28,21 & - & - & 5 & 6,41 & 27 & 34,62 \\
Unknown & 1 & 1,28 & - & - & 1 & 1,28 & 2 & 2,56 \\
\hline T o t a l & 49 & & 18 & & 11 & & 78 & 100,00 \\
\hline
\end{tabular}

Mid / Nur : Midwife/Nurse

Rel : Relative

The instruments mostly used for cut- blade, in 20 cases $(40,80 \%)$ by a sharp ting the umbilical cord were razor blade sliver bamboo and in $6(12,39 \%)$ by scis$(34,92 \%)$, scissor $(33,33 \%)$ and bamboo sors. For tying the umbilical cord after cut$(29,49 \%)$ (table 3$)$. In twenty two $(44,92 \%)$ ting, most of them used unsterile wool out of 49 cases who were attended by ligature. Most of them didn't dress the TBA, the umbilical cord was cut by razor umbilical stump.

Table 4 : Material used for umbilical stump

\begin{tabular}{lccccccccc}
\hline \multirow{2}{*}{ Material } & \multicolumn{2}{c}{ T B A } & \multicolumn{2}{c}{ Mid/Nur } & \multicolumn{2}{c}{ Rel } & \multirow{2}{*}{ Total } & $\%$ \\
\cline { 2 - 6 } & Number & $\%$ & Number & $\%$ & Number & $\%$ & & \\
\hline Alcohol/Spiritus & 11 & 14,10 & 14 & 17,95 & 1 & 1,28 & 26 & 33,33 \\
Herbal origin & 21 & 26,92 & - & - & 2 & 2,56 & 23 & 29,49 \\
Sulfa powder & 5 & 6,41 & - & - & 1 & 1,28 & 6 & 7,69 \\
Dermatol & 3 & 3,85 & - & - & 1 & 1,28 & 4 & 5,13 \\
Salicyl talcum & 1 & 1,18 & - & - & - & - & 1 & 1,28 \\
Betadine & - & - & 4 & 5,13 & - & - & 4 & 5,13 \\
Nothing & - & - & - & - & 1 & 1,28 & 1 & 1,28 \\
Unknown & 8 & 10,26 & - & - & 5 & 6,40 & 13 & 16,67 \\
\hline
\end{tabular}

In 26 cases $(33,38 \%)$ they used alcohol/ origin was used (table 4). This ingredient spiritus for the care of the umbilical stump, consisted of safron, grinded or whole while in 23 cases $(29,49 \%)$ they used ingre- Piper Betle's leaf, salt and coconut oil. The dients of herbal origin. In 21 cases $(26,92 \%)$ most common ingredient consisted of sahelped by TBA the ingredient of herbal fron, Piper Betle's and salt.

Table 5 : Education status of the parents

\begin{tabular}{|c|c|c|c|c|c|c|c|c|}
\hline \multirow{2}{*}{ Educational status } & \multicolumn{2}{|c|}{1983} & \multicolumn{2}{|c|}{1984} & \multicolumn{2}{|c|}{ Total } & \multicolumn{2}{|c|}{$o_{0}$} \\
\hline & $\mathrm{Fa}$ & Mo & $\mathrm{Fa}$ & Mo & $\mathrm{Fa}$ & Mo & $\mathrm{Fa}$ & .110 \\
\hline Illiterate & 2 & 3 & $=$ & 1 & 2 & 4 & 2.56 & 5.13 \\
\hline Elementary school & 21 & 34 & 12 & 22 & 33 & 56 & 42,32 & 71,79 \\
\hline Secondary school & 14 & 6 & 11 & 4 & 25 & 10 & 32.05 & 12,82 \\
\hline High school & 9 & 3 & 3 & - & 12 & 3 & 15,38 & 3.85 \\
\hline Academy/university & 1 & - & - & - & 1 & - & 1.28 & - \\
\hline Unknown & 3 & 4 & 2 & 1 & 5 & 5 & 6,41 & 6,41 \\
\hline Total & 50 & 50 & 28 & 28 & 78 & 78 & 100,00 & 100,00 \\
\hline
\end{tabular}

$\mathrm{Fa}=$ Father $\quad$ Mo $=$ Mother

Table 5 shows that most of the parents one case $(1,28 \%)$ in which the father grahad elementary education, namely, fathers duated from high school. $(42,32 \%)$ mothers $(71,79 \%)$. There was 


\section{Table 6 : Mortality}

\begin{tabular}{|c|c|c|c|c|c|c|c|}
\hline \multirow{2}{*}{ Year } & \multirow{2}{*}{ No of cases } & \multicolumn{2}{|c|}{$\operatorname{Rec}$} & \multicolumn{2}{|c|}{ Dis } & \multicolumn{2}{|r|}{ Death } \\
\hline & & $\mathbf{N}$ & $\%$ & 1 & $\%$ & $\mathbf{N}$ & $\%$ \\
\hline 1983 & 50 & 17 & 34 & 13 & 26 & 20 & 40 \\
\hline 1984 & 28 & 6 & 21,43 & 12 & 43,07 & 10 & 35,50 \\
\hline Total & 78 & 23 & 29,41 & 25 & 32,05 & 30 & 38,54 \\
\hline
\end{tabular}

Rec $=$ Recovery $\quad$ Dis $=$ Discharged request

Cases discharged on parent's request were not discussed in this study.

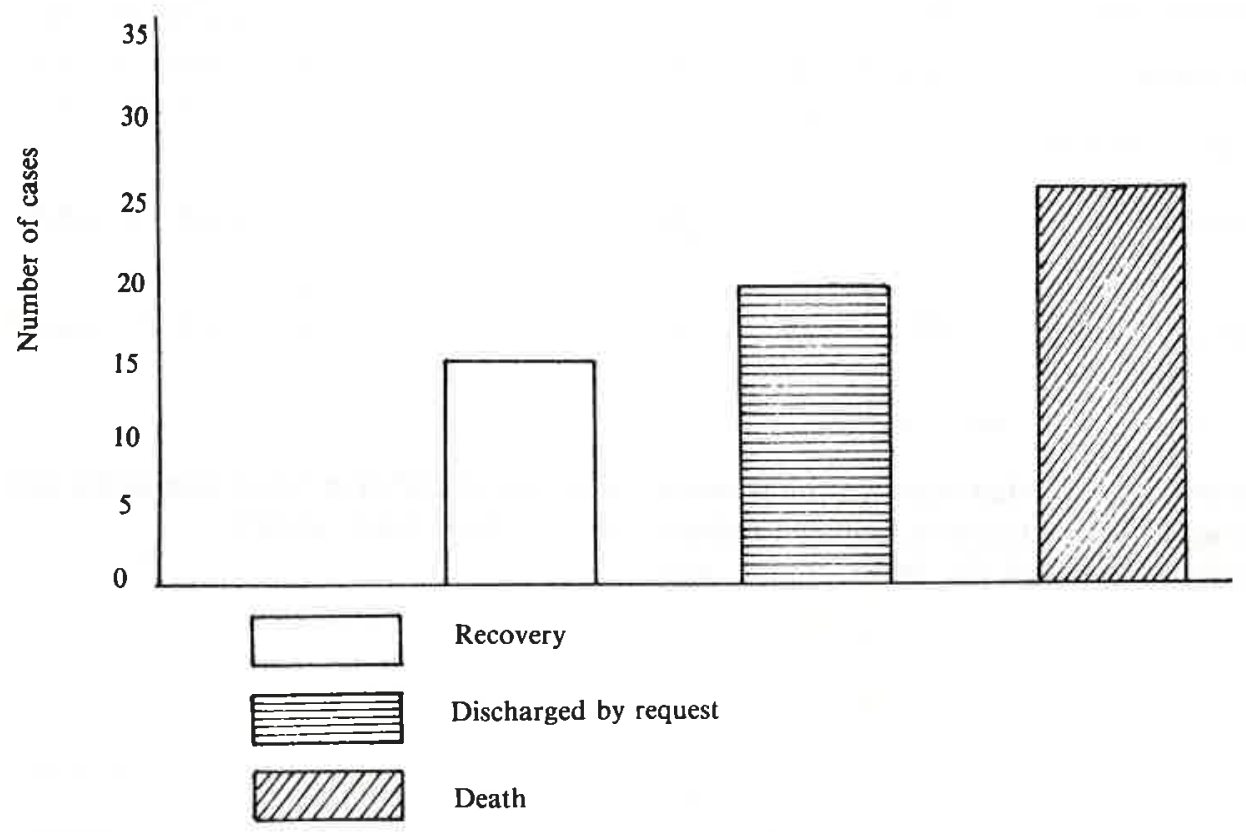

Figure 1 : The ultimate condition of neonatal tetanus cases

Table 6 and figure 1, show that 25 out The mortality rate in our cases was of 78 cases were not investigated any longer $\quad 38,54 \%$. since they were discharged by request.
Table 7 : Incubation period and mortality

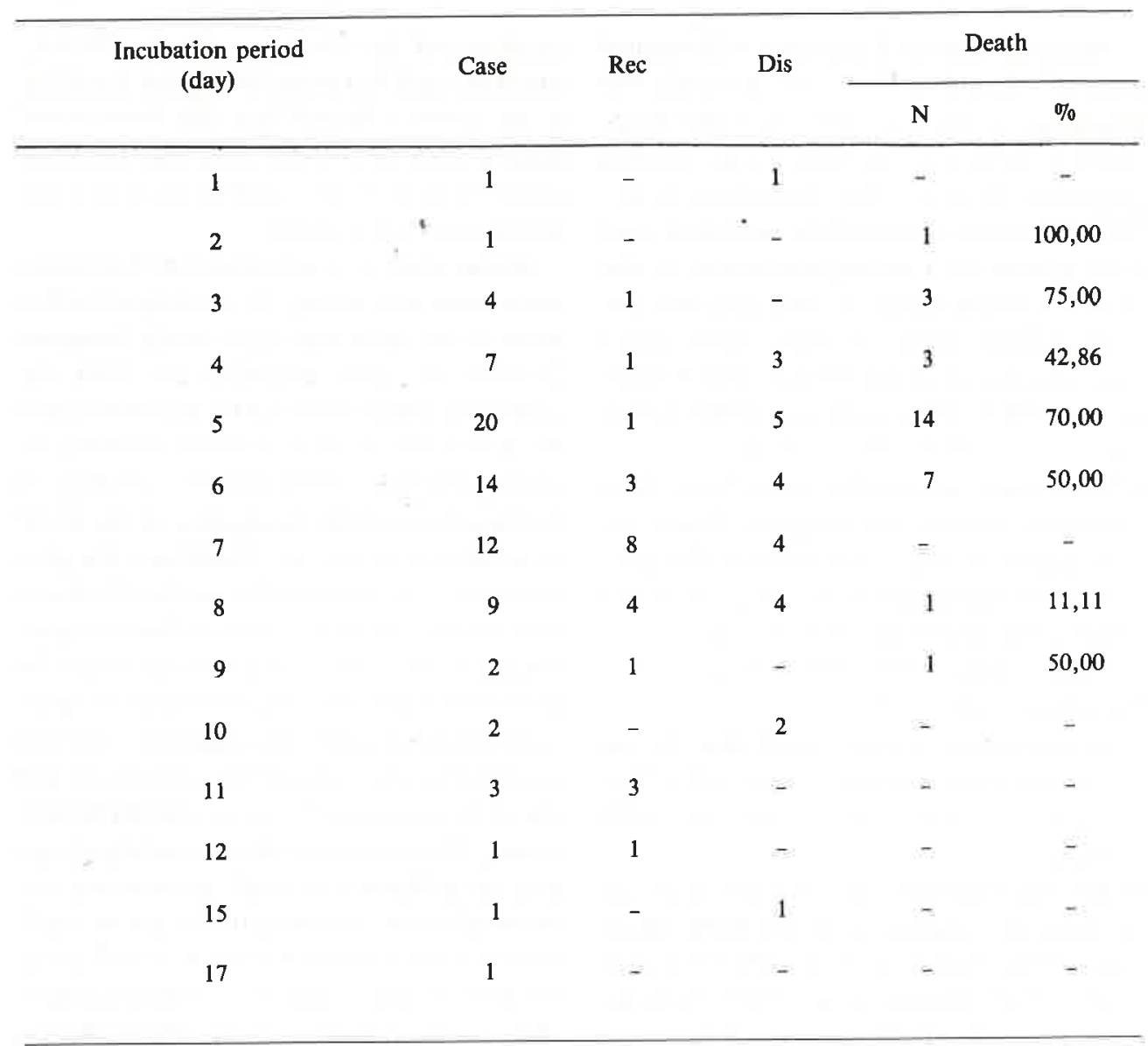

Table 8 : Mother's immunization state

\begin{tabular}{cccc}
\hline \multirow{2}{*}{ Year } & No of mother & \multicolumn{2}{c}{ T T vaccination } \\
\cline { 3 - 4 } & & Number & $\%$ \\
\hline 1983 & 50 & 0 & 0 \\
1984 & 28 & 0 & 0 \\
\hline Total & 78 & 0 & 0 \\
\hline
\end{tabular}




\section{Discussion}

Neonatal tetanus is a disease with typical emphasized by the competent officials. clinical manifestations. As a result the Marwoto and Surjono (1976) and Sudaryat diagnosis is very easy. However the treat- et al., (1981) found that the instrument ment is difficult especially in developing mostly used to cut the cord was bamboo countries (Hasan, 1981; Krugman et al., while Hamid et al., (1985) reported the 1977). Contamination of the umbilical cord application of scissors.

with spores of Clostridium tetani is the In our study it was found that the instrumost common mode of infection in new- ment used for cutting the umbilical cord in born infants whose mothers have never most of the cases was razor blade; however been vaccinated (Balakrishnan and Radha- $25.64 \%$ of cases attended by TBA the krisna, 1983; Dibyosubroto, 1980; Krug- umbilical cords were cut by bamboo (table man et al., 1977). Most of the newborn 3). It is clear that the cause of neonatal teinfants with neonatal tetanus have been tanus originates from the use of unsterile delivered outside the hospital from un- instruments and the negligance of the nurse immunized mothers. Unsterile techniques in attending deliveries. Therefore, the prowere used during delivery. The cutting and blem must be handled by medical trainers tying of the umbilical cord were done with- and staff because it is part of their responout mentioning sterility (Hucthinson, 1984; sibilities. However, regulations must be Vaughan et al., 1979).

In this study it was found that 49 out of 78 neonatal tetanus cases $(62,82 \%)$, the delivery were carried out by TBA (table 2)

Other investigators discovered such an occurrence ranging from $60-90 \%$ (Ruspanji, 1981; Sudaryat et al., 1981; Saragih et al., 1981; Hamid et al., 1985; Ismudijanto et al., 1981; Marwoto and Surjono, 1976). Only 23,08\% were attended by a midwife/nurse. Marwoto and Surjono (1976) reported 6,70\%; Ismudijanto et al., (1981) $12,5 \%$; Sudaryat et al., (1981) $20 \%$; Hamid et al., (1985) 24,39\% and Saragih et al., (1981) $31 \%$. Napitupulu (1976) in his study in 1971-1975 in Dr. Pirngadi General Hospital and PTP IX Hospital Medan found 69 occurrences out of 283 neonatal tetanus cases in which deliveries were attended by midwifes/nurses. Considering the high percentage of the cases whose deiveries were attended by midwife/nurse, it is suggested that a more appropriate control over the labor procedures should be
The mortality rate is related to the qua- in cases with an incubation period below lity of medical and nursing care given to 7 days (table 7).

the patients and also upon the severity of the The mortality rate of neonatal tetanus in disease on admission and incubation pe- several hospitals in Indonesia is presented riod. In our study the highest mortality was in table 9.

Table 9 : The mortality rate of neonatal tetanus in several hospitals in Indonesia

\begin{tabular}{lllc}
\hline Investigator & \multicolumn{1}{c}{ Year } & \multicolumn{1}{c}{ City } & Mortality rate (\%) \\
\hline Sunarto and Budiman (1972) & $1968-1969$ & Yogyakarta & 68,5 \\
Tjaij and Sembiring (1972) & $1968-1970$ & M e d a n & 73,1 \\
Husada et al., (1976) & 1972 & Manado & 75 \\
& 1973 & Manado & 50 \\
& 1974 & Manado & 72,2 \\
Napitupulu (1976) & 1975 & Manado & 61,4 \\
Saragih et al., (1981) & $1971-1975$ & M e d a n & 73,1 \\
& 1977 & M e d a n & 76,6 \\
& 1978 & M e d a n & 64,7 \\
Ruspanji (1981) & 1979 & M e d a n & 66,3 \\
Sudaryat et al., (1981) & $1979-1980$ & Banyuwangi & 35 \\
Hamid et al., (1985) & $1979-1980$ & Denpasar & 43,75 \\
Marbun et al., & 1981 & M e d a n & 66,6 \\
(This study) & 1982 & M e d a n & 70,00 \\
\hline
\end{tabular}


The use of intermittent positive pressure ventilation (IPPV) reduced the mortality rate to $18,5 \%-20 \%$ (Khoo, 1981; Balakrisnan and Radhakrisna, 1983). At the intensive care unit of the Department of Child Health Dr. Cipto Mangunkusumo Hospital 2 neonatal tetanus cases could be saved by using mechanical ventilation (Hasan, 1981). The expensive cost of modern therapy/management make look forward for more effective and practice procedure in eliminating neonatal tetanus. Neonatal tetanus is a preventable disease. Primary immunization of pregnant women with 2 doses of absorbed tetanus toxoid (TT), administered 3 times in one month interval would completely protect the newborn infants againts tetanus (Department Kesehatan R.I., 1979; Khoo, 1981; Krugman et al., 1977; Morley, 1977). In Indonesia, TT immunization was given to 900.000 expectant mothers in $1982 / 1983$ and to 993.450 in 1983/1984. Despite the increasing number of recipients it is not sufficient when compared with the popu- lation to be vaccinated. The percentage for TT in $1983 / 1984$ was $19,6 \%$. Data from the Directorat of Communicable Disease Control Provincial Health Departmen of North Sumatera showed that the outcome of the immunization of TT was $23,3 \%$ of the target while in $1983 / 1984$ was $35 \%$. It can be concluded that immunization programme must be encouraged and enhanced, because this method is an ef fective way of preventing neonatal tetanus.

The TBA plays an important role in the occurrence of neonatal tetanus. Therefore health education must be given to the TBA especially about how to help the women in delivering a baby and the proper hand ling of the umbilical cord (Krugman et al., 1977; Prawirohujo, 1980). The data from the Mother and Child Directorate Provincial Health Department of North Sumatera showed that $3213(57,33 \%)$ of TBA had been trained while in 1984, 3594 $(60,05 \%)$ out of 5985 registered TBA had been already trained. In 1982-1984 there were 286 TBA in Medan and 225 of them have been trained.

\section{Conclusion}

1. The occurrence of neonatal tetanus in neonates delivered by TBA was still high $(62,82 \%)$.

2. The percentage of TBA trained in North Sumatera was $60 \%$

3. There were also neonatal tetanus in neonates who were attended by mid wives/nurse $(23,08 \%)$.

4. The mortality rate of neonatal tetanus in the Department of Child Health Dr. Pirngadi Hospital, Medan was $38,54 \%$.

5. The coverage the TT immunization for pregnant women was relatively small; so the programme must be encouraged and enhanced.

6. Health education for community and continuing courses for the TBA should be enhanced.

\section{REFERENCES}

1. BALAKRISHNAN, $S$; RADHAKRISNA, $S$. Neonatal Tetanus. J. Pediat. Obstet. Gynaec. $9: 11-16$ (1983).

2. Departemen Kesehatan R.I.: Petunjuk Pelaksanaan Pengembangan Imunisasi hal $1-15$, Jakarta (1979).

3. DIBYOSUBROTO, S.: Management of neonatal tetanus. Mother and Child $6: 25-29$ (1980).

4. DIBYOSUBROTO, S.; RUSKANDI, M. AZHALI, M.S.: Attitude and knowledge of the parents of neonates admitted with tetanus neonatorum. Paediatr. Indones. $18: 67-74$ (1978)

5. HAMID, E.D.; DAULAY, A.P.; LUBIS, C.P. RUSDIDJAS: SIREGAR, H.: Tetanus neonatorum in babies delivered by traditional birth attendants is Medan, Indonesia. Paediatr. Indoattendants is Medan, Indons
nes. 25 : 167-174 (1985).

6. HASAN, R.: Pengobatan tetanus neonatorum dengan ventilasi mekanik, Naskah lengkap Diskusi Kelompok Tetanus Neonatorum Konika V, Medan (1981).

7. HUTCHISON, J.H.: Practical Paediatric Problem; 5th ed., pp. 87-88 (Lloyd - Luke, Asian Ed. 1984).

8. HUSADA, TJ.; RAMPENGAN, T.M.; HARJANTO, I.G.N.; ARIF, I.D.; MUNIR, M. Neonatal tetanus. Evaluation of treatment and a proposal for classification of severity, Paediatr. Indones. $16: 345-354$ (1976).

9. HUSADA, TJ.; MUNIR, M.: Neonatal tetanus analysis of 108 cases using a scoring system Paediatr. Indones. $18: 263-268$ (1978).

10. ISMUDIJANTO; KOESWARDOJO; SOEJOSO, D.A.; SOEGIJANTO, M.F.; GDE RANUH, I.G.N.: Diazepam dosis tinggi pada tetanus neonatorum. Naskah Lengkap Diskusi Kelompok Tetanus Neonatorum Konika V Medan, 1981.

11. KHOO, B.H.: Present day treatment of neonatal tetanus, Naskah Lengkap Diskusi Kelompok Tetanus Neonatorum Konika V, Medan, 1981.

12. KRUGMAN, S.; WARD, R.; KATZ, S.L
Infectionous Disease in Children; 6th ed., pp. 371-378 (Mosby, Saint Louis 1977).

13. MARWOTO and SURJONO, A.: Tetanus neonatorum in the Bethesda Hospital Yogyakarta. Paediatr. Indones. 16 : 337-344 (1976).

14. MORLEY, D.: Pediatric Priorities in the Developing World, pp. 383-385 (1977).

15. NAPITUPULU, A.: Kejadian tetanus neonatorum di RSUP Medan dan RS PTP IX Medan (1971-1975), Maj. Fak. Ked. USU No. 2/VI, pp. 2-6, Juni (1976)

16. PRAWIROHUJO, S.: Mengembangkan pelayanan kesehatan ibu dan anak sampai ke desa Pidato orari dalam Muktamar ke XVIII IDI Maado Oktober 1980, Medika 11 : 645-648 (1980).

RUSPANJI, T. Peranan keluarga pada perawatan tetanus neonatorum, Naskah Lengkap Diskusi Kelompok Tetanus Neonatorum Konika $\checkmark$, Medan, 1981.

18. SARAGIH, M.; HARAHAP, E.S.; HAMID, M.; LUBIS, C.P.; SIREGAR, H.: Kejadian tetanus neonatorum di Bagian Ilmu Kesehatan Anak RS Dr. Pirngadi Medan 1977-1979, Simposium Tetanus, Medan (1981).

19. SUNARTO; BUDIMAN, D.: Valium in the treatment of tetanus neonatorum. Paediatr. Indones. $12: 221-228$ (1972).

20. SUDARYAT; WIADNYANA, Ny. S.; SUGITHA, I.N.; WESTA, I.N.; MADRA, D.G.: Pemberian tetanus immunoglobulin human sebagai tambahan pengobatan pada tetanus neonatorum, Naskah Lengkap Diskusi Kelompok Tetam Neonatorum Konik V, Medan, 1981.

1. TJAIJ, J.K,; SEMBIRING, L: Modi TJAIJ, J.K.; SEMBIRING, L.: Modified treatment of neonatal tetanus. Paediatr. Indones. $12: 229-234$ (1972).

22. VAUGHAN, V.C.; MC. KAY, R.J.; BEHRMAN, R.E.: Tetanus, in Nelson Text Book of Pediatrics, 11th. ed. pp. 804-807 (Saunders, Igaku Shoin, Philadelphia/London/Toronto/ Tokyo 1979)

23. UMPAN BALIK E.P.O.D. Penyakit-penyakit Pengembangan Program Immunisasi, 47 (1984). 